\title{
Two new setose species of Marasmius from the Paraná riparian forest in Argentina
}

\author{
Nicolás NIVEIRO ${ }^{a, b^{*}}$, Andrea MICHLIG ${ }^{a, b}$, Natalia Andrea RAMÍREZ $^{a, b}$, \\ Carlos Alberto SALVADOR-MONTOYA ${ }^{a}$, María Laura PÉREZ ${ }^{a, c}$, \\ Edgardo Omar ALBERTÓ ${ }^{d}$ \& Vladimír ANTONÍN ${ }^{e}$
}

${ }^{a}$ Instituto de Botánica del Nordeste, IBONE (UNNE-CONICET). Sargento Cabral 2131, CC 209, Corrientes Capital, CP 3400, Argentina; email:andrea.michlig@yahoo. com; nataliaandrearamirez@hotmail.com.ar; csalvador05@gmail.com

${ }^{b}$ Departamento de Biología, Facultad de Ciencias Exactas y Naturales y Agrimensura, Universidad Nacional del Nordeste. Av. Libertad 5470, Corrientes Capital, CP 3400, Argentina.

${ }^{c}$ Facultad de Ciencias Agrarias, Universidad Nacional del Nordeste. Sargento Cabral 2131, CC 209 Corrientes Capital, CP 3400,Argentina; email: p_mlaura@hotmail.com

${ }^{d}$ Instituto de Investigaciones Biotecnológicas- Instituto Tecnológico de Chascomús. IIB-INTECH (UNSAM-CONICET). Cam. Circ. Laguna Km. 6, Chascomús, Buenos Aires, CP 7130, Argentina; email: eoalberto@gmail.com

${ }^{e}$ Department of Botany, Moravian Museum, Zelný trh 6, 65937 Brno, Czech Republic; email: vantonin@mzm.cz

\begin{abstract}
The aim of this article is to describe two new setoid species of Marasmius: $M$. chrysoblepharioides and $M$. neotrichotus from the riparian forest of the Paraná river in Northeastern Argentina. Marasmius chrysoblepharioides is characterized by a sulcate-striate, yellowish orange pileus, an entirely pilose, orange brown stipe; caulosetae with a tapering and thick-walled apex, and its bacilliform to fusiform basidiospores. Marasmius neotrichotus differs from $M$. trichotus and $M$. ciliatus by its longer caulosetae and spores, respectively. The phylogenetic analyses based on molecular data from ITS sequences indicated that both new species are distinct from closely related species.
\end{abstract}

Agaricales / Basidiomycota / diversity / Marasmiaceae / M. chrysoblepharis / M. trichotus / Sicci / Spinulosi / taxonomy

\section{INTRODUCTION}

Marasmius Fr. (Marasmiaceae, Agaricales) comprises ca. 500 species worldwide (Kirk et al., 2008) and more than 1900 epithets recorded in the Index Fungorum website (http://www.indexfungorum.org/Names/Names.asp?pg=1). Due

\footnotetext{
* Corresponding author: Nicolás Niveiro, email address: niconiveiro@gmail.com
} 
to its important diversity and abundance, the genus plays an essential role in litter decomposition, particularly in tropical and subtropical forests (Braga-Neto et al., 2008; López-Quintero et al., 2012). Marasmius species are characterized by their generally small to medium-size basidiomata, membranaceous consistency, narrow, cartilaginous stipe, and reviviscent habit (Singer, 1976). This last feature allows them to tolerate seasonal drought or high temperatures (Singer, 1986). Microscopically, the basic character is a hymeniform pileipellis (e.g. Antonín \& Noordeloos, 2010).

Marasmius comprises many infrageneric divisions which are based mainly on characters such as the type of broom cells forming the pileipellis, presence or absence of a collarium, the stipe attachment to the substrate (insititious or noninsititious), and the pseudoamyloid (= dextrinoid) or non-amyloid (= non-dextrinoid) trama (Singer, 1976, 1986). However, Wannathes et al. (2009a) and Oliveira et al. (2014) have recently tested the monophyly of the sections traditionally proposed by Singer $(1958,1976)$, and confirm that they are highly homoplasic.

A small group of species of Marasmius is characterized by having very thick-walled and acuminate cystidia (setae) on the hymenophore, pileus and stipe surface together with a hymeniform pileipellis of broom cells of the Siccus-type (e.g. M. actinopus, M. jalapensis, M. coharens). Singer (1958) grouped setose species of Marasmius in the series Actinopodes Singer, within section Sicci Singer; while Desjardin (1989) distributed them into two different series: Spinulosi (Clémençon) Desjardin (species with setae) and Atrorubentes Desjardin \& E. Horak (species with conspicuous caulocystidia, which do not form setae with thickened walls).

The species of Marasmius with setae are not common, being better known from southeastern Asia (Pegler, 1986; Desjardin et al., 2000; Tan et al., 2009; Wannanthes et al., 2009a; Antonín et al., 2010; Ryoo et al., 2013) and the Neotropical region (Singer, 1976; Pegler, 1983; Desjardin \& Ovrebo, 2006; Puccineli \& Capelari, 2006). In the north of Argentina, about 90 species of Marasmius are known, many of them described by Spegazzini and Singer (Niveiro \& Albertó, 2013), and some species were recently described by Lechner \& Papinutti (2011) and Papinutti \& Lechner (2011).

The aim of this article is to describe two new setose species of Marasmius from the riparian forest of Paraná river, in northeastern Argentina.

\section{MATERIAL AND METHODS}

\section{Collections}

The specimens studied here were collected in the floodplain on the western bank of Paraná river from Chaco province in northern Argentina, and deposited in CTES Herbarium. These specimens were macroscopically described according to Largent (1986). Colour names are in accordance with Kornerup \& Wanscher (1978). For the microscopic characters, a light microscopy (LM) Leica model CME was used. All LM images were made with a Leica EC3 incorporated camera of material mounted in 5\% KOH and Phloxine (1\%), or Melzer's reagent. The measurements were made directly in the LM or through the photographs taken using the software ImageJ (Schneider et al., 2012). Microstructures (length and width of basidiospores, basidia, hyphae, pileipellis) were measured in LM. The following notations were 
used for the basidiospores' measurement: $\mathrm{x}=$ arithmetic mean of the basidiospore length and width; $Q=$ quotient of length and width indicated as a range of variation; $\mathrm{Q}_{\mathrm{x}}=$ mean of $\mathrm{Q}$ values; $\mathrm{n}=$ number of basidiospores measured, $\mathrm{N}=$ number of analysed basidiomata. All GPS readings were taken on a Garmin eTrex 10, hand held unit using WGS84 standard. Herbarium abbreviations follow Index Herbariorum (Thiers, 2017) and the authors' abbreviations follow Kirk \& Ansell (1992).

The specimens analysed were identified using different generic dichotomous keys (Moser, 1983; Raithelhuber, 2004; Antonín \& Noordeloos 2010; Niveiro et al., 2014), Marasmius specific dichotomous keys (Singer, 1965, 1976; Desjardin et al., 2000; Tan et al., 2009; Wannathes et al., 2009a; Shay et al., 2017), and descriptions found in the specific literature (Singer, 1989; Antonín et al., 2010).

\section{DNA extraction, amplification, and sequencing}

Genomic DNA of the two new species was isolated from dried basidiomata tissue following standard protocols of the Canadian Centre for DNA barcoding (CCDB) for fungi (Ivanova et al., 2006, 2016; Fazekas et al., 2012). Approximately $20 \mathrm{ng}$ of DNA were used for polymerase chain reaction (PCR) amplifications of the nuclear ribosomal internal transcribed spacer (ITS) region of the DNA, with primers ITS1-F and ITS4-B (Gardes \& Bruns, 1993), which was suggested as the universal DNA barcode marker for fungi (Ivanova et al., 2008; Schoch et al., 2012). Forward and reverse strands were purified and sequenced by Macrogen Inc. (Seoul, South Korea). The ITS sequences retrieved in this study were deposited into GenBank database. Collection data and GenBank accession numbers of the specimens used in this study are detailed in Table 1.

\section{Phylogenetic analysis}

The resulting sequences were assembled and manually edited using Geneious v. 6.1.8 (Kearse et al., 2012). These sequences were aligned together with 40 sequences retrieved from GenBank (NCBI) (Table 1), mainly of representatives of ser. Spinulosi/Atrorubentes, which were treated by Wannathes et al. (2009a, b), Oliveira et al. (2014), and Shay et al. (2017). Crinipellis malesiana Kerekes, Desjardin \& Vikinesw. was used as outgroup for phylogenetic inferences (Wannathes et al., 2009a).

The sequences alignment was initially perform with MAFFTv.7 (under the Q-INS-i criteria) (Katoh \& Standley, 2013) and manually edited using MEGA6 (Tamura et al., 2011). The final ITS dataset included 44 specimens, and was subdivided into three data partitions: ITS1, 5.8S, and ITS2. The best fit model of nucleotide evolution to the dataset was selected using AIC (Akaike Information Criterion) as implemented in jModelTest2 v.1.6 (Guindon \& Gascuel, 2003; Darriba et al., 2012).

The dataset was analysed with Maximum Likelihood (ML) and Bayesian Inference (BI) approaches. ML searches were conducted with RaxML-HPC v.8 (Stamatakis, 2014), searching for the best scored trees with GTRGAMMA model for the entire dataset with all the default parameters estimated by the software. The analysis first involved 100ML independent searches each one starting from one randomized stepwise addition parsimony tree. Only the best scored ML tree was kept, and the confidence of nodes was accessed through non-parametric bootstrapping (BS) replicates under the same model, allowing the program to stop bootstrapping 
TABLE 1: ITS dataset of Marasmius used in the phylogenetic analyses, itemized by infrageneric group.

\begin{tabular}{|c|c|c|c|}
\hline Species & Section / Serie & Collection No. & $\begin{array}{c}\text { ITS GenBank Accession } \\
\text { No. }\end{array}$ \\
\hline M. galbinus $^{b}$ & Globulares & GDGM 27251 & HQ709445 \\
\hline M. laticlavatus ${ }^{i}$ & Globulares & NW 412 & EU643511 \\
\hline M. laticlavatus ${ }^{i}$ & Globulares & NW 293 & EU643512 \\
\hline M. auratus ${ }^{h}$ & Sicci/ Atrorubentes & NW 076 & EU935501 \\
\hline M. auratus $^{h}$ & Sicci/ Atrorubentes & NW 175 & EU935502 \\
\hline M. corrugatiformis $f$ & Sicci/ Atrorubentes & Buyck 97425 & KX148981 \\
\hline M. inthanonensish & Sicci/ Atrorubentes & NW 414 & EU935514 \\
\hline M. iras $^{h}$ & Sicci/ Atrorubentes & NW 276 & EU935486 \\
\hline M. iras $^{h}$ & Sicci/ Atrorubentes & NW 375 & EU935487 \\
\hline M. jasminodorus ${ }^{h}$ & Sicci/ Atrorubentes & NW 294 & EU935515 \\
\hline M. jasminodorus ${ }^{h}$ & Sicci/ Atrorubentes & NW 353 & EU935514 \\
\hline M. katangensis ${ }^{f}$ & Sicci/ Atrorubentes & JES 227 & KX148991 \\
\hline M. luteolus ${ }^{h}$ & Sicci/ Atrorubentes & NW 138 & EU935506 \\
\hline M. luteolus ${ }^{h}$ & Sicci/ Atrorubentes & NW 304 & EU935507 \\
\hline M. ochroleucus ${ }^{h}$ & Sicci/ Atrorubentes & NW 299 & EU935503 \\
\hline M. ochroleucus ${ }^{d}$ & Sicci/ Atrorubentes & LE 295978 & KF912952 \\
\hline M. pseudopellucidus ${ }^{h}$ & Sicci/ Atrorubentes & NW 186 & EU935504 \\
\hline M. pseudopellucidus ${ }^{h}$ & Sicci/ Atrorubentes & NW 305 & EU935505 \\
\hline M. strobiluriformis ${ }^{a}$ & Sicci / Atrorubentes & BRNM 714914 & GU266263 \\
\hline M. strobiluriformis ${ }^{a}$ & Sicci / Atrorubentes & BRNM 714915 & GU266264 \\
\hline M. xestocephalus ${ }^{h}$ & Sicci/ Atrorubentes & JFK 69 & EU935488 \\
\hline M. xestocephalus ${ }^{h}$ & Sicci/ Atrorubentes & NW 344 & EU935489 \\
\hline M. siccus $^{h}$ & Sicci / Haematocephali & BRNM 552709 & HQ607384 \\
\hline M. siccus $^{d}$ & Sicci / Haematocephali & LE 295980 & KF774130 \\
\hline M. acerosus $^{g}$ & Sicci / Leonini & TYS 427 & FJ431214 \\
\hline M. acerosus $^{g}$ & Sicci / Leonini & TYS 458 & FJ431213 \\
\hline M. adhaesus ${ }^{g}$ & Sicci / Leonini & TYS 467 & FJ431216 \\
\hline M. adhaesus $^{g}$ & Sicci / Leonini & TYS 464 & FJ431217 \\
\hline
\end{tabular}




\begin{tabular}{|c|c|c|c|}
\hline M. olivascens ${ }^{c}$ & Sicci / Leonini & TYS 424 & FJ431266 \\
\hline M. olivascens ${ }^{c}$ & Sicci / Leonini & TYS 426 & FJ431265 \\
\hline M. chrysoblepharioides & Sicci / Spinulosi & CTES 0568164 & MF683956 \\
\hline M. chrysoblepharioides & Sicci / Spinulosi & CTES 0568166 & MF683957 \\
\hline M. dendrosetosus ${ }^{f}$ & Sicci / Spinulosi & JES 205 & KX148995 \\
\hline M. dendrosetosus ${ }^{f}$ & Sicci / Spinulosi & JES 211 & KX148996 \\
\hline M. jalapensis & Sicci / Spinulosi & CTES 0568170 & MF683959 \\
\hline M. longisetosus ${ }^{e}$ & Sicci / Spinulosi & JO 248 & JX424040 \\
\hline M. neotrichotus & Sicci / Spinulosi & CTES 0568167 & MF683958 \\
\hline M. nummularius ${ }^{h}$ & Sicci / Spinulosi & NW 266 & EU935492 \\
\hline M. nummularius ${ }^{h}$ & Sicci / Spinulosi & NW 396 & EU935493 \\
\hline M. nummularius ${ }^{h}$ & Sicci / Spinulosi & JES 121 & KX148979 \\
\hline M. trichotus $^{h}$ & Sicci / Spinulosi & NW 262 & EU935490 \\
\hline M. trichotus $^{h}$ & Sicci / Spinulosi & NW 263 & EU935491 \\
\hline Crinipellis malesiana $^{g}$ & - & TYS 346 & FJ167628 \\
\hline Crinipellis malesiana $^{c}$ & - & BO_AR 491 & NR119706 \\
\hline
\end{tabular}

Published sequences are found in: a- Antonín et al. (2012), b- Deng \& Li (2011), c- Kerekes \& Desjardin (2009), dKiyashko et al. (2014), e- Oliveira et al. (2014), f- Shay et al. (2017), g- Tan et al. (2009), h- Wannathes et al. (2009a), i- Wannathes et al. (2009b).

automatically by the autoMRE option. An additional alignment partition file to force RAxML software to search for a separate evolution model for each partition was used. BI analyses were carried out with Mr.Bayes 3.2.6 (Ronquist \& Huelsenbeck, 2003), and implemented with two independent runs, each one beginning from random trees with four simultaneous independent chains. A total of $2 \times 10^{7}$ generations were carried out, sampling one tree every $1 \times 10^{3}$ generation. The initial $25 \%$ of the sampled trees was discarded as burn-in and checked by the convergence criterion (frequencies of average standard deviation of split $<0.01$ ) in Tracer v.1.6 (Rambaut et al., 2014), while the remaining ones were used to reconstruct a 50\% majority-rule consensus tree and to estimate Bayesian posterior probabilities (BPP) of the branches. J Model Test2 v.1.6, Mr Bayes 3.1.2 and RaxML-HPC v. 8.2.3 were used in CIPRES science gateway (Miller et al., 2010; http://www.phylo.org/). A node was considered to be strongly supported if it showed a BPP $\geq 0.95$ and/or $\mathrm{BS} \geq 90 \%$, while moderate support was considered $\mathrm{BPP} \geq 0.9$ and/or $\mathrm{BS} \geq 70 \%$.

Only the topology from the best $\overline{M L}$ tree is shown, indicating support values (BPP/BS) of each node. The alignment was deposited in TreeBASE (http:// www.treebase.org/treebase/index.html), under accession number 21518. 


\section{RESULTS}

\section{Molecular phylogeny}

The dataset includes 44 sequences belonging to 2 species of the series Spinulosi, Atrorubentes, Leonini and Haematocephali of the sect. Sicci, one of the sect. Globulares, and four newly generated sequences, resulting in an alignment with 637 characters, of which 427 are constant sites, 210 variable and 163 parsimony informative. The best evolutionary model estimated for each dataset were TPM $2 \mathrm{uf}+\mathrm{G}$, $\mathrm{K} 80$ and TPM1uf $+\mathrm{G}$, for ITS1, 5.8S and ITS2, respectively. In the phylogenetic inferences from nITS dataset (Fig 1), the sect. Sicci and ser. Atrorubentes were recovered as polyphyletic, in comparison to the traditional classification of Singer (1976). A major monophyletic clade was recovered, including the species of the sect. Globulares and ser. Haematocephali, Spinulosi and Atrorubentes of the sect. Sicci $(\mathrm{BS}=88 / \mathrm{BPP}=1)$; and having as sister clade an assemblage composed of species of ser. Leonini, but unsupported. The others species of ser. Atrorubentes (named here as Atrorubentes p.p.) of sect. Sicci did not form a monophyletic group. The Spinulosi + Atrorubentes p.p. clade is a strongly supported group $(\mathrm{BS}=98 / \mathrm{BPP}=1)$ and appears as the sister to some specimens of Marasmius sect. Globulares (BS=98/BPP=0.99) and together are sister to Marasmius siccus (ser. Haematocephali) with strong support $(\mathrm{BS}=88 / \mathrm{BPP}=1)$. The newly described $M$. chrysoblepharioides (MF683956,



Fig 1. Maximum likelihood (ML) tree of Marasmius based on dataset of ITS sequences. Bayesian posterior probability above 0.9 and Bootstrap values above $70 \%$ are shown. ( $\mathrm{T}=$ Type). 
MF683957) and M. neotrichotus (MF683958) are included within Spinulosi + Atrorubentes p.p. Marasmius neotrichotus (MF683958) was sister to M. trichotus E.J.H. Corner in a well-supported clade $(\mathrm{BS}=82 / \mathrm{BPP}=0.92)$. The two sequences of M. chrysoblepharioides formed a monophyletic group $(\mathrm{BS}=100 / \mathrm{BPP}=1)$, basal to the other members of the clade Spinulosi + Atrorubentes p.p. Although in the phylogenetic tree a longer branch length is observed for MF683957, we consider both sequences belong to the same species as they are $95 \%$ similar. This genetic distance is probably due to the non-optimal quality of the obtained sequence, which included 10 ambiguous sites. In this paper, we introduce two new species following the recommendation of Jeewon \& Hyde (2016) for describing new taxon based on molecular data.

\section{Taxonomy}

Marasmius chrysoblepharioides Niveiro \& Ramírez, sp. nov.,

Figs $\mathbf{2}-\mathbf{1 3}$

Mycobank: MB 823883

Genbank: MF683956 (ITS, holotype), MF683957 (ITS, paratype)

Holotype: ARGENTINA, Chaco, $1^{\circ}$ de Mayo, floodplain forest, on the margin of the Parana river, $27^{\circ} 25^{\prime} 43.11^{\prime \prime} \mathrm{S}, 058^{\circ} 51^{\prime} 58.73^{\prime \prime} \mathrm{W}, 52 \mathrm{~m}$ a.s.1., on leaf litter, 07 January 2014, N. Niveiro SI 15-24 (CTES 0568164).

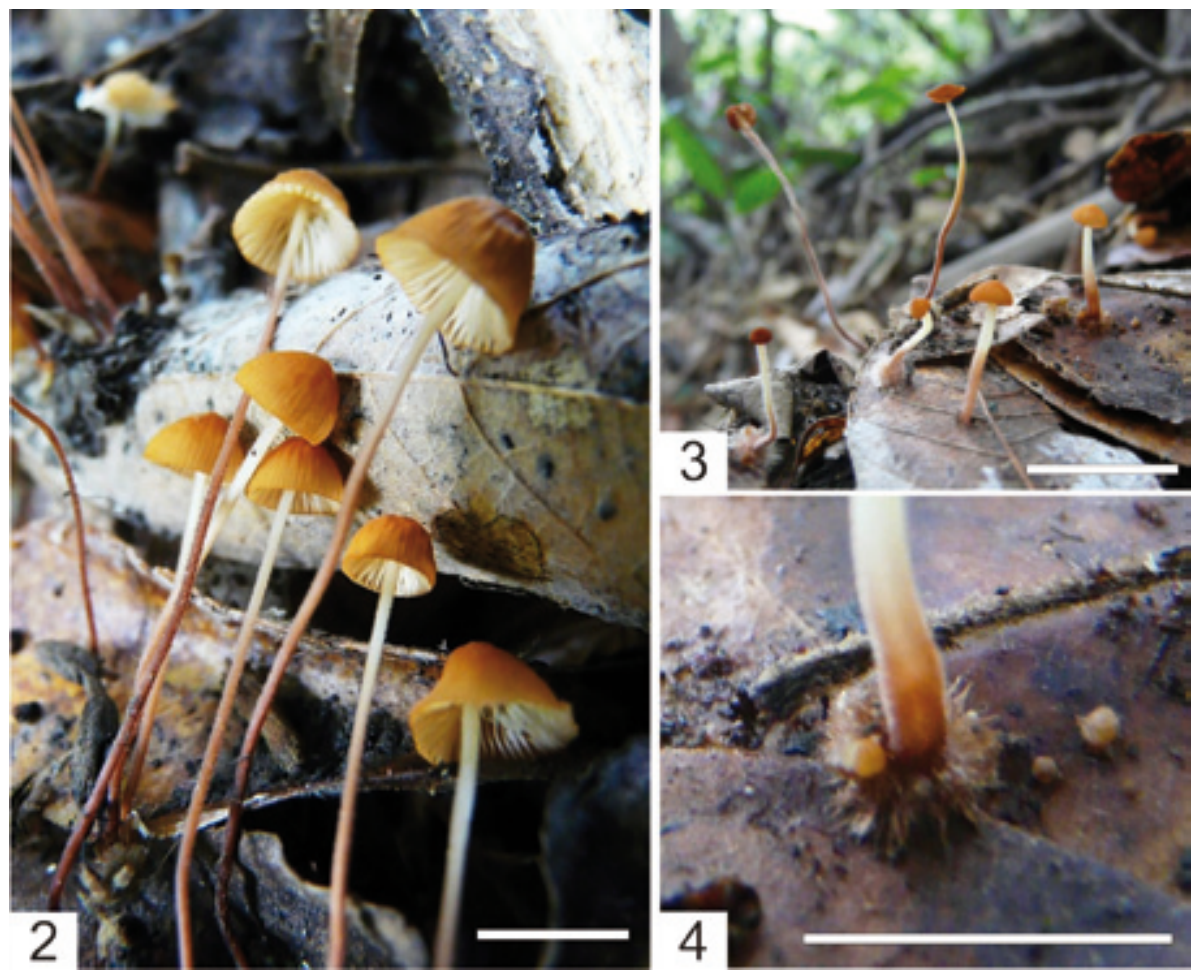

Figs 2-4. M. chrysoblepharioides general aspect. 2. Mature basidiomata. 3. Young basidiomata. 4. Base of the stipe in a young basidiomata. Scale bar: $2=20 \mathrm{~mm} ; 3-4=10 \mathrm{~mm}$. 
Diagnosis. Marasmius chrysoblepharioides is characterized by a sulcatestriate, yellowish orange pileus; entirely pilose, orange brown stipe; caulosetae 28.5-23.5 × 6-13.8 $\mu \mathrm{m}$, with a tapering and thick-walled apex, and its bacilliform to fusiform basidiospores measuring $15-19 \times 3.5-4.5 \mu \mathrm{m}$.

Etymology. The epithet refers to the similarity with $M$. chrysoblepharis.

Basidiomata reviviscent. Pileus up to $25 \mathrm{~mm}$ broad, convex-hemispheric to broadly paraboloid, golden yellow (5B7) to pale orange (5A3) or light orange (5A4) at the margin when fresh, orange (5A7) to golden yellow (5B7) at the centre (Figs 2-4), ferrugineous (7A7-7C7) when dried; surface dry, glabrous, margin sulcate (Figs 5-8). Context very thin, white (5A1) to cream (5A2), membranaceous. Odor and taste indistinct. Lamellae subdistant, $\mathrm{L}=11-14$, with three series of lamellulae,

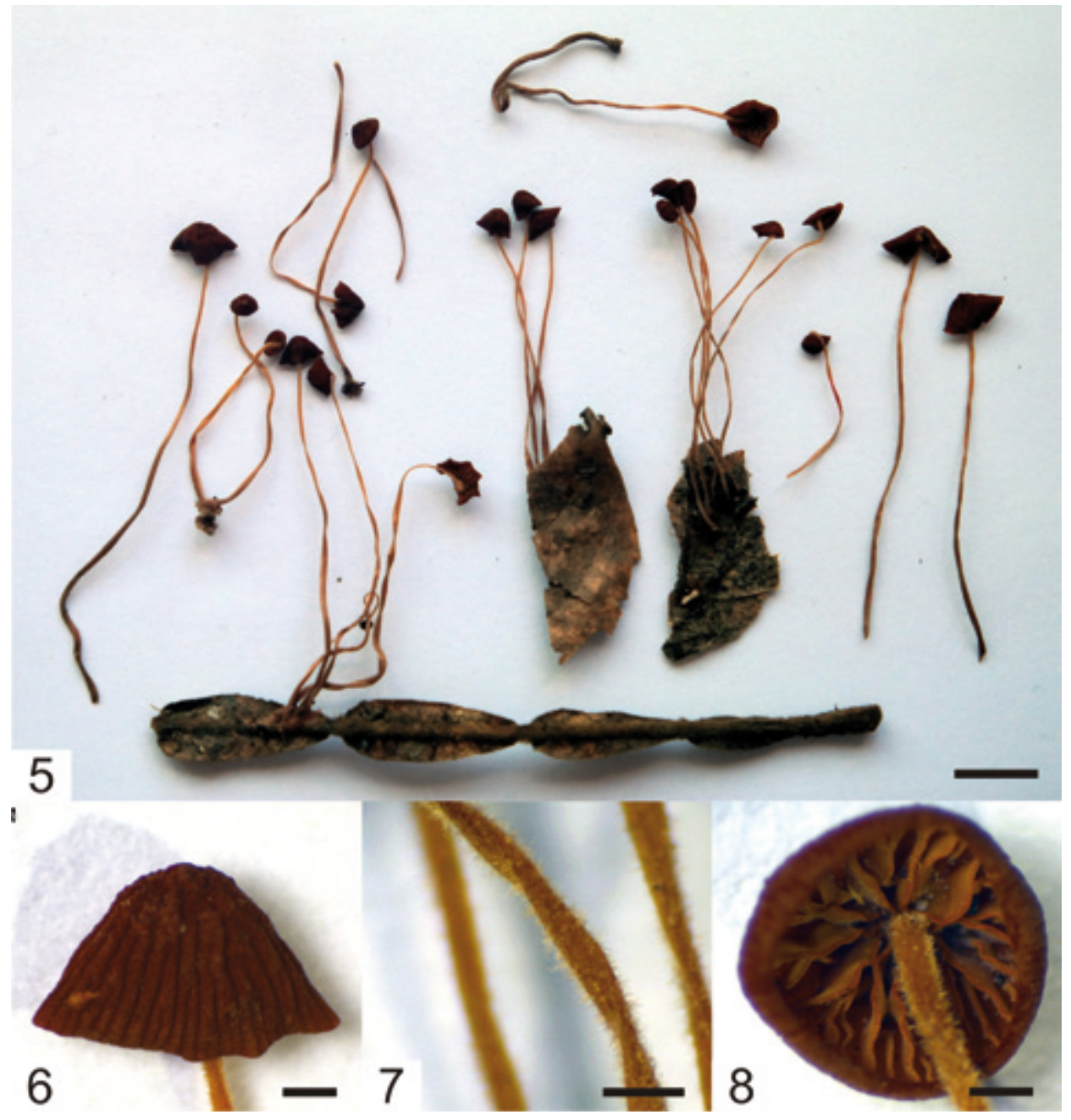

Figs 5-8. M. chrysoblepharioides dehydrated type specimen. 5. General aspect. 6. Detail of the pileus surface. 7. Detail of the stipe surface. 8. Detail of the lamellae. Scale bar: $5=10 \mathrm{~mm} ; 6-8=1 \mathrm{~mm}$. 
adnexed to adnate, cream (5A1-5A2); edge entire, concolorous with the side of the lamellae, or in some parts concolorous with the pileus surface; not intervenose (Figs 2, 8). Stipe 20-40 × 0.3-1 mm, central, terete, equal, hollow, cartilaginous, dark brown (7E7-7F8) to reddish brown (7C8-7B7), the apex orange-pallid (6B3-6B4); surface entirely hispid, dry, non-insititious; arising from an abundant greyish orange (6B5) to pale orange (6A3) basal mycelium (Figs 2-4, 7). Spore print whitish (6A1).

Basidiospores 15-19 $\times 3.5-4.5 \mu \mathrm{m}, x=17.2 \times 4 \mu \mathrm{m}, \mathrm{Q}=3.7-4.9, \mathrm{Q}_{\mathrm{x}}=$ 4.2, $\mathrm{n}=50, \mathrm{~N}=3$; bacilliform, fusiform to subfusiform, thin-walled, smooth, hyaline, inamyloid (Fig 9). Basidia 22-27 × 6-7 $\mu \mathrm{m}$, clavate, 4-spored, thin-walled (Fig 10). Basidioles 29-39 $\times 5-8 \mu \mathrm{m}$, fusiform with a mucronate apex, thin-walled, hyaline (Fig 11). Pleurocystidia absent. Cheilocystidia like the pileipellis broom cells, but with longer setulae; main body $19-29.5 \times 4.7-7.5 \mu \mathrm{m}$, clavate, thin-walled, hyaline; apical setulae up to $7 \mu \mathrm{m}$ long, conical to cylindrical with obtuse to subacute apex, hyaline to yellowish-hyaline or to golden yellow wall (Fig 12). Hymenophoral trama regular; hyphae 2.5-4.5 $\mu \mathrm{m}$ diam., hyaline, dextrinoid. Pileipellis hymeniform, composed of Siccus-type broom cells, 12.5-18.5 × 4.0-6.5 $\mu \mathrm{m}$, cylindrical, clavate or irregular in outline, thin-walled, with setulae up to $4 \mu \mathrm{m}$ long. Pileocystidia absent. Stipitipellis hyphae 3-6 $\mu \mathrm{m}$ diam., cylindrical, subparallel, smooth, yellowish, dextrinoid, thick-walled (up to $1 \mu \mathrm{m}$ ), non-gelatinous, with abundant caulosetae. Caulosetae 28.5-235 × 6-13.8 $\mu \mathrm{m}$, simple, widened at base, with a tapering apex; with walls up to $2 \mu \mathrm{m}$ thick, ochraceous, inamyloid (Fig 13). Clamp connections present in all tissues.

Habit and habitat: mycenoid, gregarious, on leaf-litter.

Specimens studied: ARGENTINA, Chaco, $1^{\circ}$ de Mayo, in floodplain forest, on the margin of the Parana river, $27^{\circ} 25^{\prime} 43.11^{\prime \prime} \mathrm{S}, 058^{\circ} 51^{\prime} 58.73^{\prime \prime} \mathrm{W}, 52 \mathrm{~m}$ a.s.1., 11 November 2013, N. Ramírez \& N. Niveiro SI 5-12 (CTES 0568166, paratype); Ibid., 07 January 2014, N. Niveiro SI 15-25 (CTES 0568165).

Additional specimens and species examined: Marasmius chrysoblepharis Singer: MEXICO, Veracruz, Tlilapan, banks of Rio Aserradero, 24 June 1969, Singer M8201 (holotype, F). Marasmius flammans Berk.: BRAZIL, Panuré, on dead leaves, R. Spruce 97 [holotype, K(M) 200554].

Observations: Marasmius chrysoblepharioides is characterized by its yellowish orange pileus with a sulcate-striate margin, an orange brown, entirely pilose stipe, larger basidiospores and caulocystidia than those in closely allied species, and by lacking cystidia on both pileus surface (pileocystidia) and hymenophore (pleurocystidia). Macroscopically, M. chrysoblepharis Singer is the most similar species, however, it differs by smaller basidiospores $(9.3-13 \times 3.3-3.7$ $\mu \mathrm{m}$ ) and smaller caulocystidia (up to $120 \mu \mathrm{m}$ long) (Singer, 1976). In our morphological analysis of M. chrysoblepharis type material [Singer M8201(F)!], we found bacilliform to fusiform basidiospores $(9.4-10.7 \times 3.2-4.0 \mu \mathrm{m})$ and setiform caulocystidia $(34-95 \times 4.5-5.0 \mu \mathrm{m})$, thick-walled (walls up to $1 \mu \mathrm{m}$ thick) and with a rounded-obtuse apex or an acute papilla (Fig 14-17), which corroborates that both species have this distinctive character.

Other morphologically similar species that resemble $M$. chrysoblepharioides are M. nummularius Berk. \& Broome and M. nummularioides Desjardin \& Y.S. Tan. The former is widely distributed from southeastern Asia (Pegler, 1986; Desjardin et al., 2000; Wannathes et al., 2009a) and to Madagascar (Shay et al., 2017). Marasmius nummularius differs in forming smaller basidiospores that do not exceed $15 \mu \mathrm{m}$ in length $(10-15 \times 3-5.5 \mu \mathrm{m})$, shorter caulocystidia $(20-150 \times 6-36 \mu \mathrm{m})$ and a darker coloured pileus surface (dark reddish brown to dark brownish orange) (Desjardin et al., 2000; Shay et al., 2017). The second species, M. nummularioides, has a more 


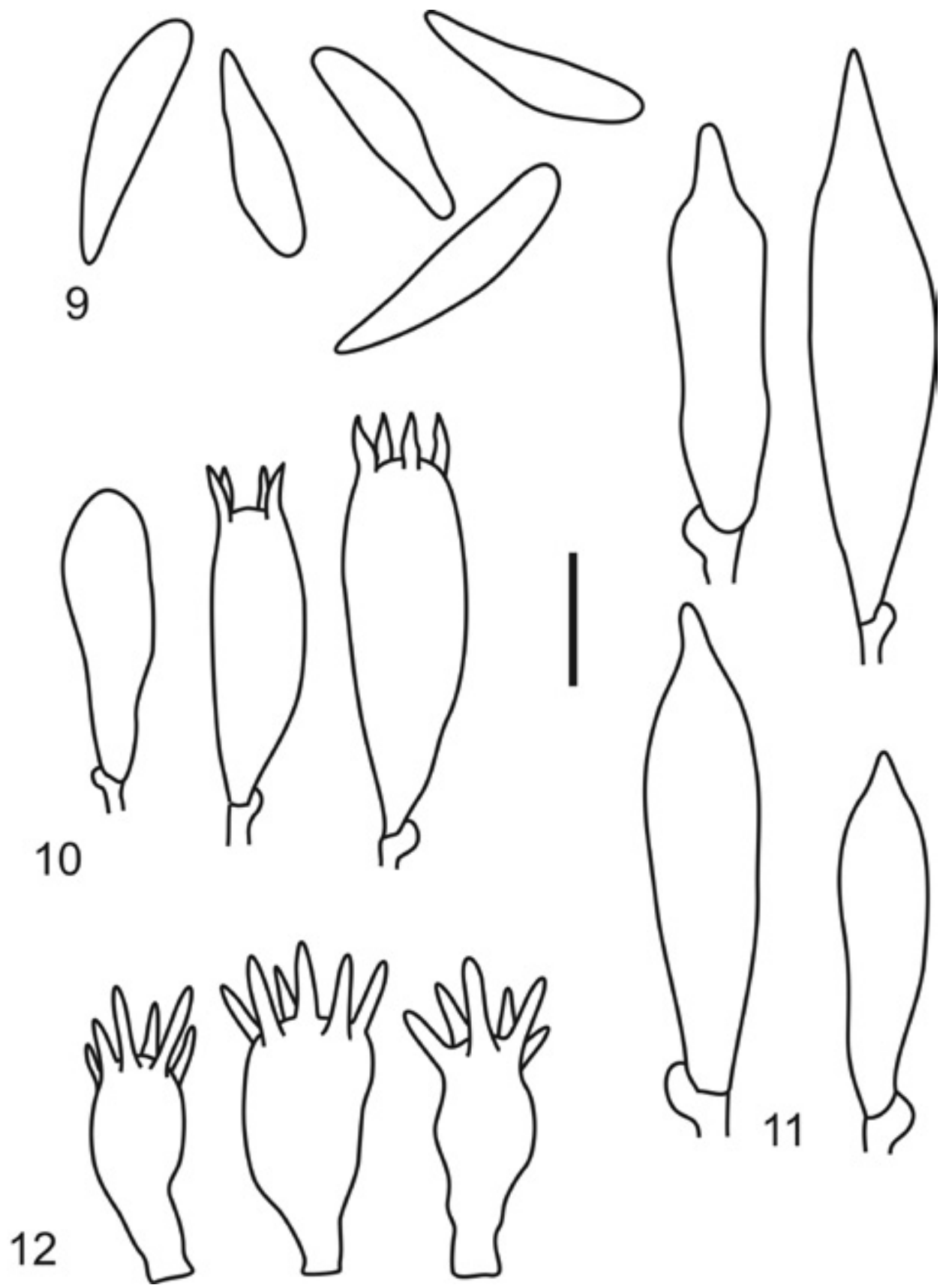

Figs 9-12. M. chrysoblepharioides microscopic characters. 9. Basidiospores. 10. Basidia. 11. Basidioles. 12. Cheilocystidia. Scale bar $=10 \mu \mathrm{m}$. 


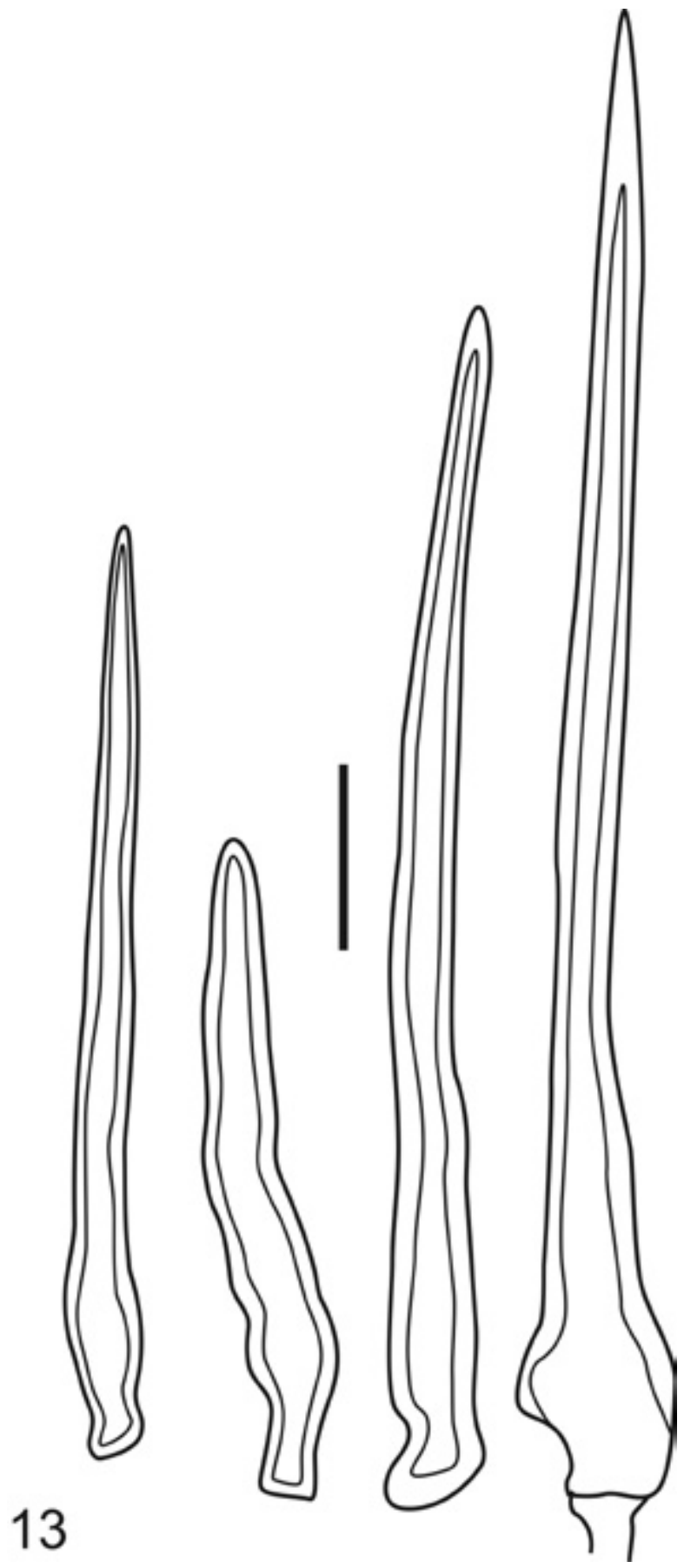

Fig 13. M. chrysoblepharioides microscopic characters. Caulocystidia. Scale bar $=20 \mu \mathrm{m}$. 

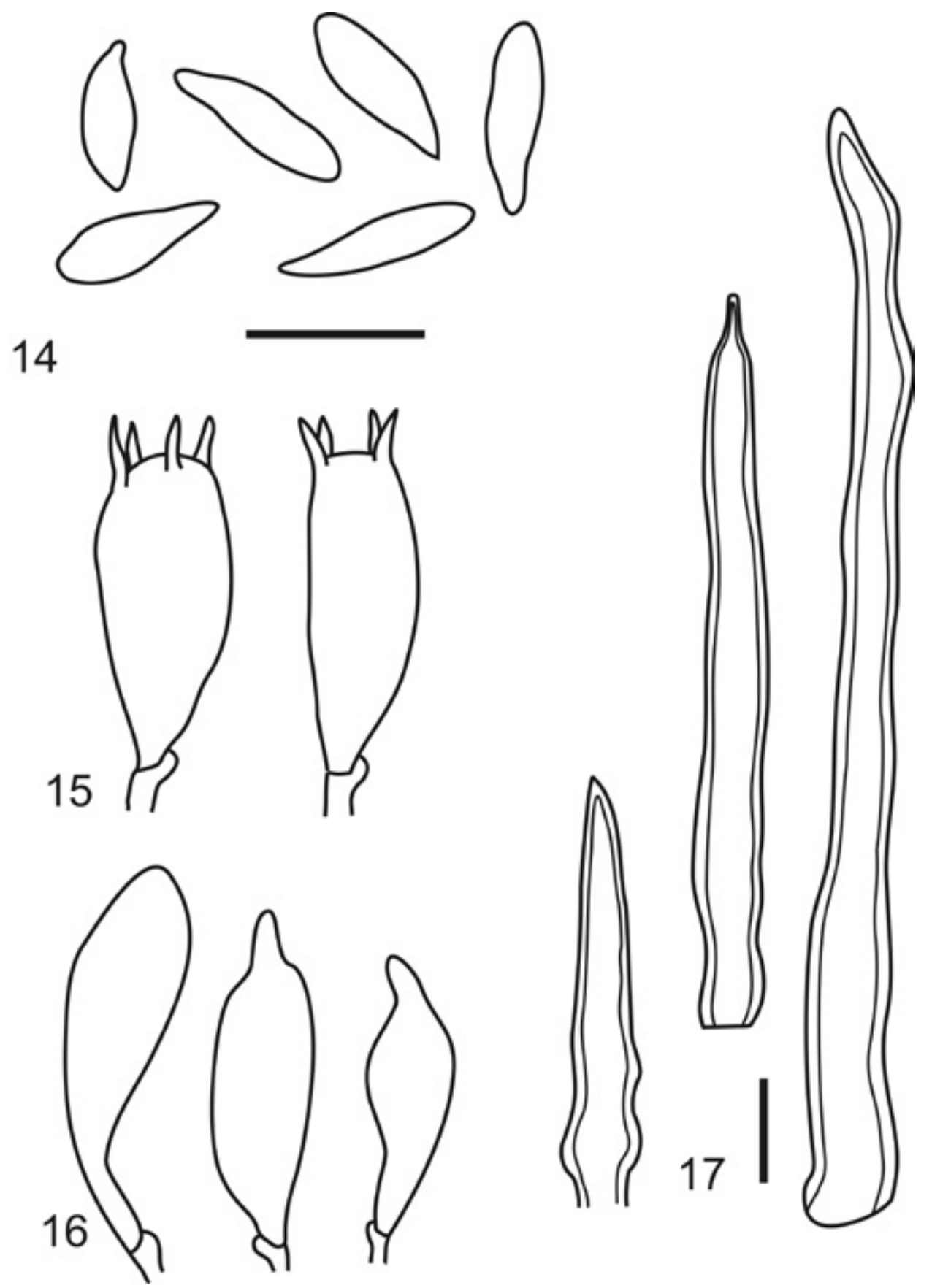

Figs 14-17. M. chrysoblepharis microscopic characters. 14. Basidiospores. 15. Basidia. 16. Basidioles. 17. Caulocystidia. Scale bar $=10 \mu \mathrm{m}$. 
restricted distribution to the Malaysian Peninsular, however, it is distinguished by its non-striate pileus margin, a reddish brown pileus surface, darker than in $M$. chrysoblepharioides, and Siccus-type caulocystidia together with setiform structures in the stipitipellis (Tan et al., 2007, 2009).

Marasmius longisetosus J.S. Oliveira \& Capelari, described from Brazil (Oliveira et al., 2014) and M. dendrosetosus Shay \& Desjardin, recently described from Madagascar (Shay et al., 2017), are two phylogenetically closely related species. The former clearly differs in having a smaller, reduced and curved stipe, elongated pileosetae in the pileipellis, the stipitipellis bearing caulocystidia of the Siccus-type broom cells without setiform caulocystidia, and smaller basidiospores (up to $12 \mu \mathrm{m}$ long., Oliveira et al., 2014). Marasmius dendrosetosus, has a cream to orangish-white pileus surface, antler-like pileosetae and caulocystidia of the Siccus-type (Shay et al., 2017).

There are other, less known South American species of Marasmius that resemble $M$. chrysoblepharioides that deserve to be mentioned for some morphological and ecological similarites. Marasmius flammans was described from Brazil, and is known only from the type specimen. It is similar to $M$. chrysoblepharioides by its basidiomata size and colouration. However in a redescription of this species, Dennis (1951) and Singer $(1958,1976)$ showed that M. flammans [R. Spruce $97-$ K(M) 200554!] has a glabrous stipe, numerous setiform hymenial cystidia, and welldeveloped pileosetae, which are not present in $M$. chrysoblepharioides. More recently, Singer (1989) described several Marasmius species from the Brazilian Amazon, many of them in flooded river margins, a similar environment where $M$. chrysoblepharioides was found. Among them, two species belonging to sect. Sicci have a pilose or velutinous stipe surface: $M$. asemiformis Singer and $M$. asemus Singer. Both species differ from $M$. chrysoblepharioides in their shorter caulocystidia (10-50 $\times 3-9 \mu \mathrm{m}$ in M. asemiformis and 20-30 $\times 3.5-6.5 \mu \mathrm{m}$ in M. asemus) without thickened walls, characters that would include them to ser. Atrorubentes. Another distinctive character is that both species have smaller basidiospores: 7-11 $\times 2.5-3.7$ $\mu \mathrm{m}$ in M. asemiformis, and 9-11.5 × 3.5-4.5 $\mu \mathrm{m}$ in M. asemus (Singer, 1989).

Other related species without pileosetae and pleurocystidia, M. opulentus Har. Takah. described from Japan, has a deep orange to orange pileus, smaller basidiospores, 8-10 $\times 3.5-4 \mu \mathrm{m}$, and two types of caulocystidia, (1) irregularly cylindrical to fusoid, thick-walled cells, and (2) Siccus-type cells with long setulae (Takahashi, 2000). Marasmius atrocastaneus G. Stev., known from New Zealand, has a deep brown, chestnut brown, orangish brown or reddish brown pileus, smaller basidiospores [(9-)10-12 × 4.5-5.5 $\mu \mathrm{m}]$, and smaller caulosetae, 30-80 $\times 4-8 \mu \mathrm{m}$ (Desjardin \& Horak, 1997).

Marasmius neotrichotus Niveiro, Ramírez \& Antonín, sp. nov.,

Figs 18-33

Mycobank: MB 823884

Genbank: MF683958 (ITS, holotype)

Holotype: ARGENTINA, Chaco, $1^{\circ}$ de Mayo, in floodplain forest, on the margin of the Parana river, $27^{\circ} 25^{\prime} 43.11^{\prime \prime} \mathrm{S}, 058^{\circ} 51^{\prime} 58.73^{\prime \prime} \mathrm{W}, 52 \mathrm{~m}$ a.s.1., 25 November 2013, N. Ramírez \& N. Niveiro SI 7-13 (CTES 0568167).

Diagnosis. Marasmius neotrichotus differs from $M$. trichotus by having longer caulosetae and from $M$. ciliatus by its larger spores.

Etymology. The epithet refers to the similarity with $M$. trichotus and its Neotropical distribution.

Basidiomata reviviscent. Pileus up to $20 \mathrm{~mm}$ broad, convex to planoconvex, with a shallow central depression, brownish orange (6C6-6C8) with darker 


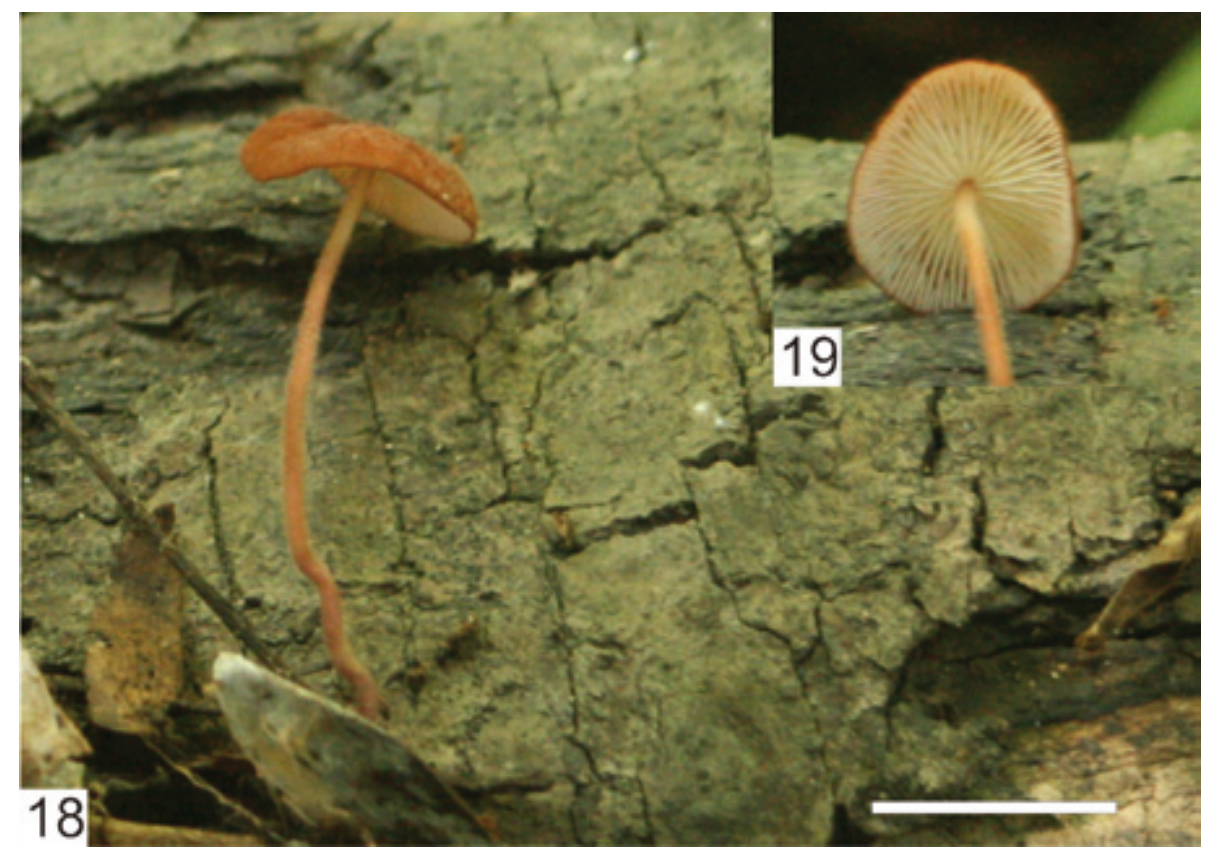

Figs 18-19. M. neotrichotus general aspect. Scale bar $=20 \mathrm{~mm}$.

centre with blackish stains, light brown (6D6-6D7), reddish brown to dark brown (8E6-8F6) when dried; surface dry, velutinous to velvety, margin smooth to slightly striate when fresh (Figs 18, 21). Context thin, whitish (4A1-4B1), membranaceous. Odor and taste indistinct. Lamellae close, $\mathrm{L}=20-24$, with three series of lamellulae, adnexed to free, white (4A1) to cream (4A2); edge entire, concolorous with the lamellae sides; not intervenose (Fig 22). Stipe $18-40 \times 0.5-1.2 \mathrm{~mm}$, central, terete, straight, equal, hollow, cartilaginous, brownish orange (6C5-6C7) to reddish brown (7A4-7A5), pallid toward the apex, light orange (6A4) to pale orange (6A3); surface densely hispid, dry; arising from a basal mycelium, whitish (4A2) to cream (4C3) (Figs 20, 23). Spore print whitish (4A1-4A2).

Basidiospores 9-15 × 3.5-5 $\mu \mathrm{m}, x=12.2 \times 4.2 \mu \mathrm{m}, \mathrm{Q}=2-3.2, \mathrm{Q}_{\mathrm{x}}=2.8$, $\mathrm{n}=40, \mathrm{~N}=2$; cylindrical, fusiform to bacilliform, thin-walled, smooth, hyaline, inamyloid (Fig 24). Basidia 20-24 × 6-8 $\mu \mathrm{m}$, clavate, 4-spored, thin-walled (Fig 25). Basidioles 22-28 $\times 6-7.5 \mu \mathrm{m}$, fusiform with a mucronate apex, thin-walled, hyaline (Fig 26). Pleurocystidia absent. Cheilocystidia abundant, composed of Siccus-type broom cells; main body 19-24 × 4.5-6.5 $\mu \mathrm{m}$, clavate, thin-walled, hyaline; apical setulae up to $5 \mu \mathrm{m}$ long, conical to cylindrical with obtuse to subacute apex, hyaline to yellowish-hyaline or to golden yellow wall (Fig 27). Hymenophoral trama regular, consisting of hyaline hyphae, 1.5-5 $\mu \mathrm{m}$ diam, dextrinoid. Pileipellis hymeniform, composed of Siccus-type broom cells, 18-22.5 $\times 6.5-7.5 \mu \mathrm{m}$, cylindrical, clavate or irregular in outline, thin- to slightly thick-walled, with spines up to $4 \mu \mathrm{m}$ long. Pileosetae 80-370 $\times 5-9 \mu \mathrm{m}$, needle-shaped, thick-walled, walls 1.5-3 $\mu \mathrm{m}$ wide, brown, abundant, scattered among pileipellis cells (Fig 28-29). Stipitipellis hyphae 3-5 $\mu \mathrm{m}$ diam., cylindrical, subparallel, smooth, yellowish to brownish, inamyloid, thick-walled (up to $1 \mu \mathrm{m}$ ), non-gelatinous, with abundant 


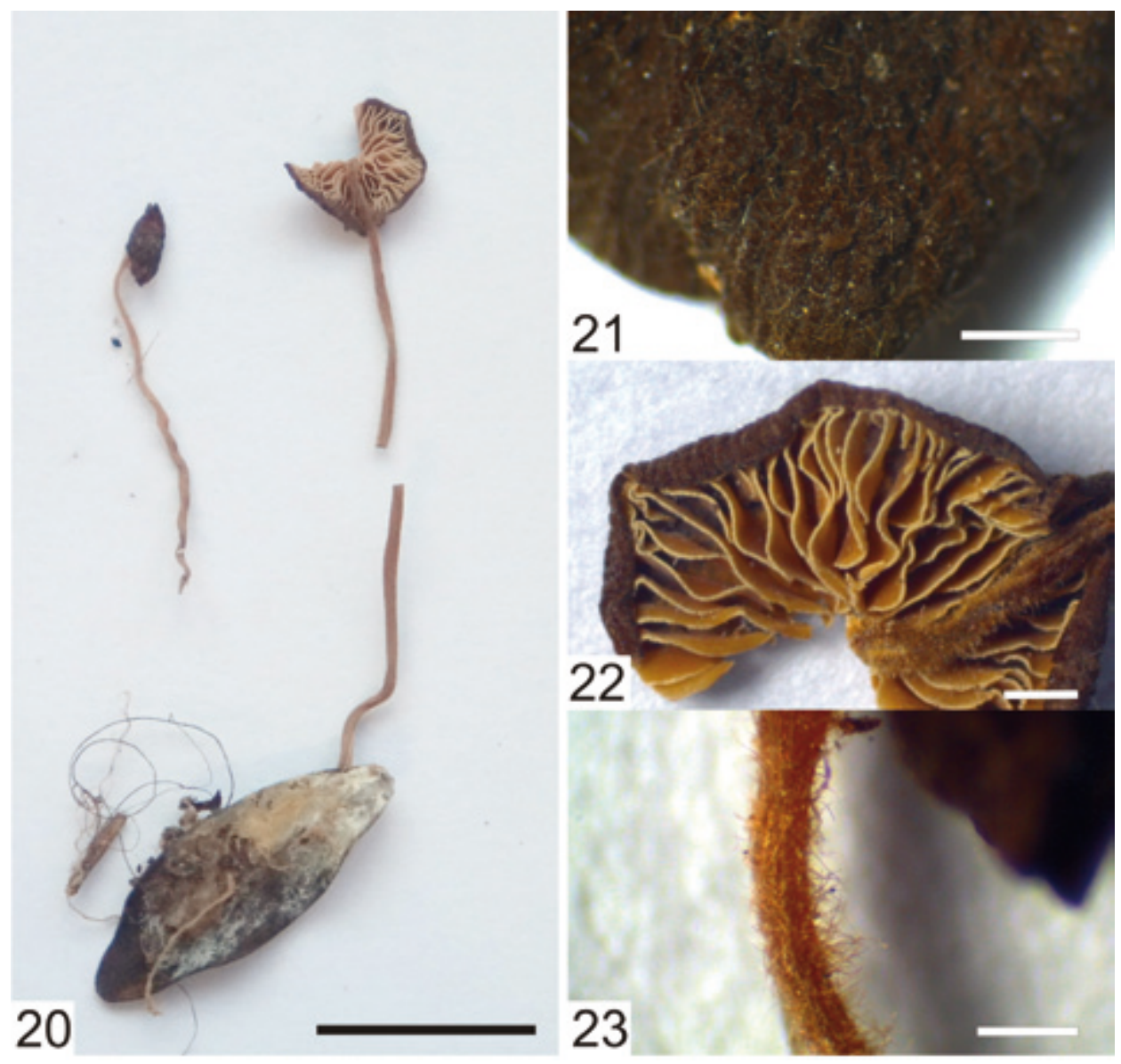

Figs 20-23. M. neotrichotus dehydrated type specimen. 20. General aspect. 21. Detail of the pileus surface. 22. Detail of the lamellae. 23. Detail of the stipe surface. Scale bar: $20=10 \mathrm{~mm}, 21-23=1$ $\mathrm{mm}$.

caulocystidia. Caulocystidia of two types, a) caulosetae, 40-480 $\times 5-15 \mu \mathrm{m}$, with a tapering apex, thick-walled, walls $0.8-2 \mu \mathrm{m}$ wide, brown, very abundant, some with few spine-like branches (Figs 30-32); and b) transitional irregular elements between Siccus-type broom cells and setae, thin-walled, some formed by a main body 8-13 $\times 4-9 \mu \mathrm{m}$ in size, with 3 to 6 apical setulae, up to $40 \mu \mathrm{m}$ long similar to Siccus-type broom cells, others formed by an unique small erect setae, up to $70 \times 10 \mu \mathrm{m}$, with 3 to 5 branches like as lateral spines, the spines up to $40 \mu \mathrm{m}$ long, scarce and rare (Fig 33). Clamp connections present.

Habit and habitat: collybioid, gregarious, on fallen leaves.

Specimens studied: ARGENTINA, Chaco, $1^{\circ}$ de Mayo, in floodplain forest, on the margin of the Parana river, $27^{\circ} 25^{\prime} 43.11^{\prime \prime} \mathrm{S}, 058^{\circ} 51^{\prime} 58.73^{\prime \prime} \mathrm{W}, 52 \mathrm{~m}$ a.s.1., 25 November 2013, N. Ramírez \& N. Niveiro SI 7-14 (CTES 0568183), 24 March 2014, N. Ramírez \& N. Niveiro SI 22-5 (CTES 0568184). 

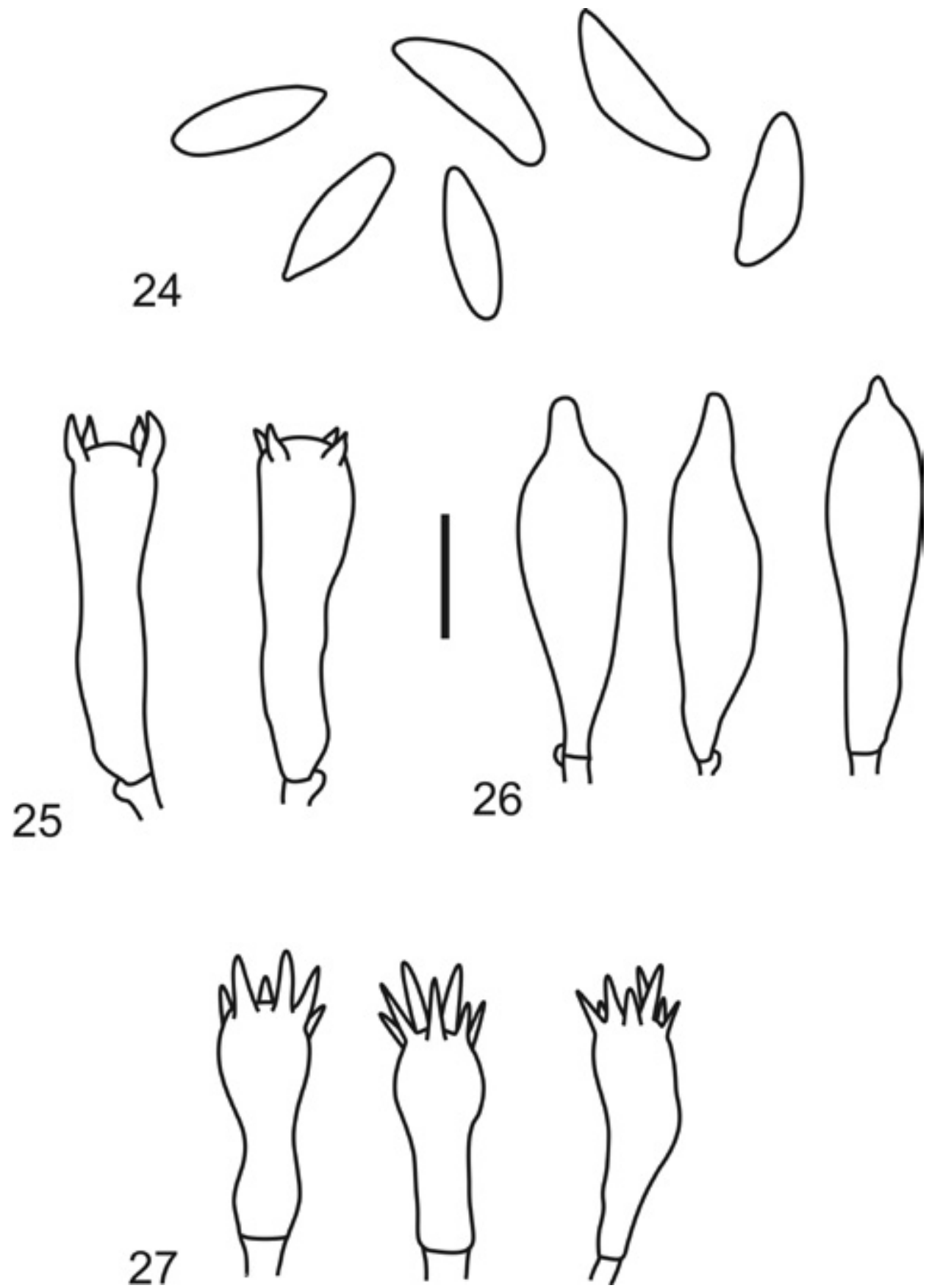

Figs 24-27. M. neotrichotus microscopic characters. 24. Basidiospores. 25. Basidia. 26. Basidioles. 27. Cheilocystidia. Scale bar $=10 \mu \mathrm{m}$. 


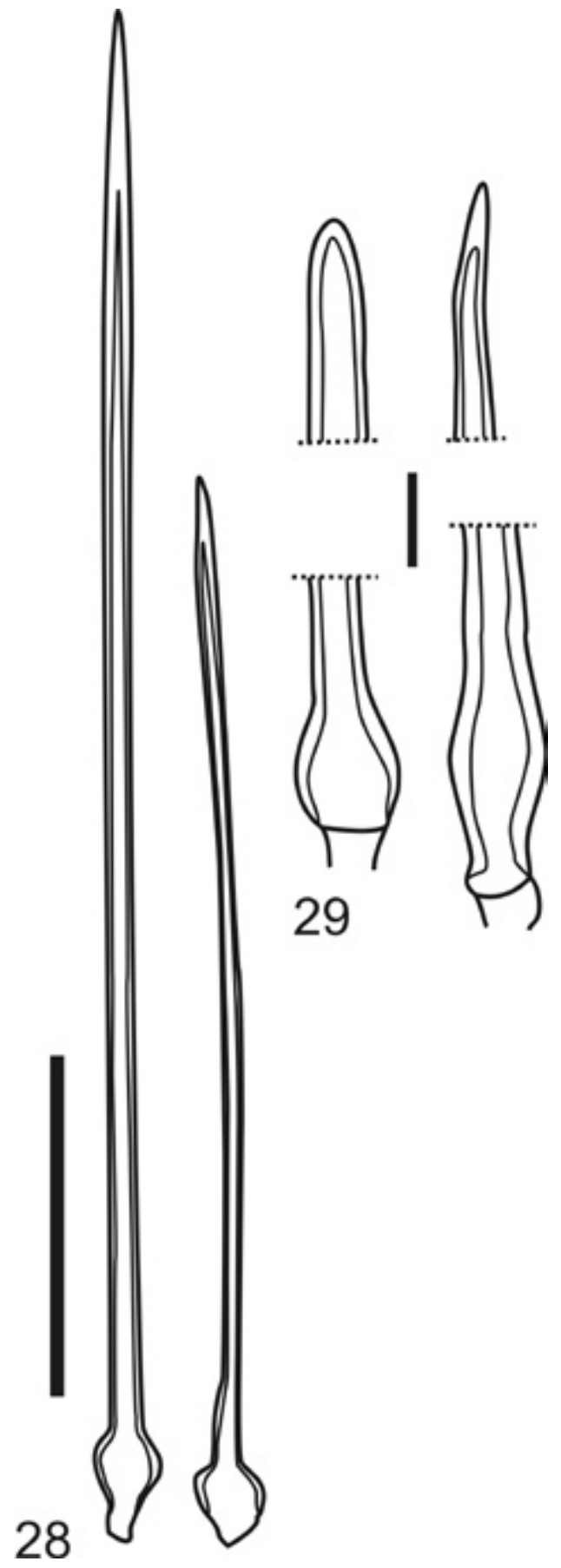

Figs 28-29. M. neotrichotus microscopic characters. 28. General aspect of the pileocystidia. 29. Detail of the base and apex of the pileocystidia. Scale bar: $28=100 \mu \mathrm{m}, 29=10 \mu \mathrm{m}$. 

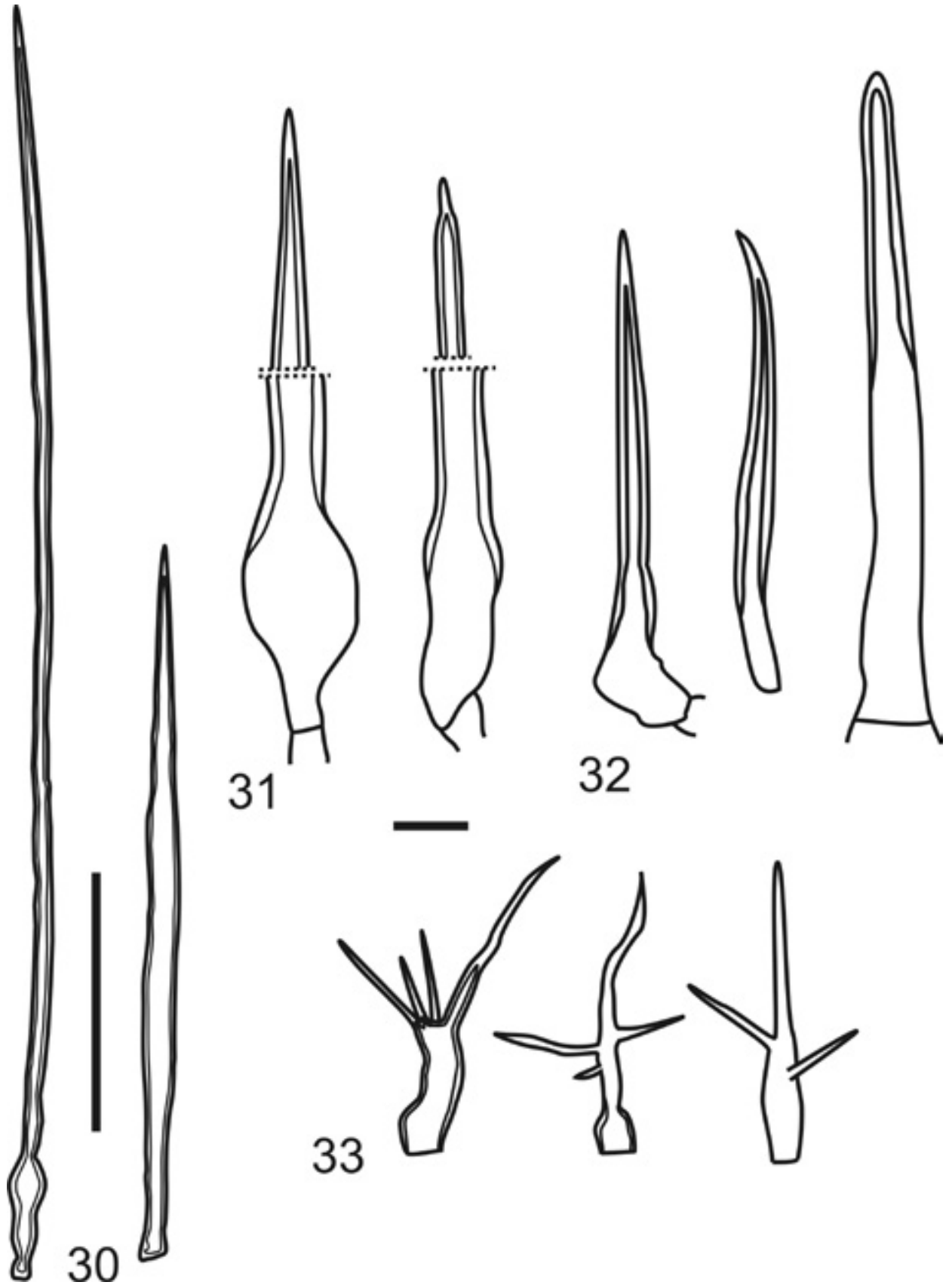

Figs 30-33. M. neotrichotus microscopic characters. 30. General aspect of the setiform caulocystidia. 31. Detail of the base and apex of the setiform caulocystidia. 32. Short setiform caulocystidia. 33. Transitional caulocystidia. Scale bar: $30=100 \mu \mathrm{m} ; 31-33=10 \mu \mathrm{m}$. 
Additional specimens and species examined: Marasmius ciliatus Pegler: MARTINIQUE, Vallee inferior de la Rivere Lorrain, on dead rotting leaves of Swietenia sp., 30 September 1977, D.N. Pegler 2906 [holotype, K(M) 200556]. Precheur, anse couleuvre superieur, 23 September 1977, D.N. Pegler 2840 [K(M) 200555]. - Marasmius spiculosus Singer: BOLIVIA, La Paz, Nor Yungas, Rio Yariza, $1450 \mathrm{~m}$ a.s.1., on rotting wood, 16 February 1956, R. Singer B1206 (holotype, LIL). - Marasmius trichotus E.J.H. Corner: SINGAPORE, Gardens Jungle, 18 March 1943, E.J.H. Corner s/n (holotype, E, liquid collection, as "Crinipellis 5").

Observations: Marasmius neotrichotus is characterized by its long pileosetae and caulosetae, the presence of irregular elements transitional between the Siccustype broom cells and setae as the second type of caulocystidia, the non-striated pileus margin and close white lamellae. These characters make it very similar to $M$. trichotus, described form southeastern Asia and $M$. ciliatus, described from the Lesser Antilles. All together constitutes a species complex that shares small basidiomata, covered by extraordinarily long setiform cystidia (hairs). In the original description, Corner (1996) described $M$. trichotus with a pileus "4-6 mm wide, fawn brown, wholly pilose with short erect ochraceous hairs" and a "wholly puberulous scurfy" stipe. Microscopically, he described the pileipellis with numerous hairs up to $300 \mu \mathrm{m}$ long, with a ventricose base with thickened pale brown walls, and tapering in an acute apex. However, he did not describe the hairs of stipe surface. In the holotype [Corner s/n, E!], we observed 80-210 $\mu \mathrm{m}$ long setiform cystidia on the pileus surface and caulocystidia in the form of modified broom cells, composed of a basal body, with 2-6 setiform projections of 45-70 $\mu \mathrm{m}$ long, thick-walled (Figs 34-38), differing clearly from those observed in $M$. neotrichotus. Wannathes et al. (2009a) described abundant fusoid to lanceolate setiform cystidia on the pileus (60$300 \mu \mathrm{m}$ long) and stipe surface (22-213 $\mu \mathrm{m}$ long) for $M$. trichotus from Thailand, explaining also that those populations differ from those in Singapore (type locality) in the slightly paler and larger pileus, characters that resemble the species here described.

Marasmius ciliatus differs in its smaller basidiomata, pileus not exceeding $10 \mathrm{~mm}$ diam., and the shorter basidiospores, 7.5-10.5 $\times 4-5 \mu \mathrm{m}$ in size. The type specimen [Pegler 2906 - K(M) 200556!] consists of one complete basidioma and three stipes without any remnants of pileus. Due to the scarcity of material, only a small portion of stipe and lamellae was analysed. We observed numerous fusiform basidioles, 19-24 × 6-8 $\mu \mathrm{m}$, with mucronate, occasionally rostrate apex, and cheilocystidia in the form of the Siccus-type broom cells with main body 15-19 $\times$ 5-7 $\mu \mathrm{m}$ in size, and setulae up to $6 \mu \mathrm{m}$ long and $1 \mu \mathrm{m}$ diam., thin-walled and hyaline. On the stipe surface, we observed very long setiform hairs, up to $500 \mu \mathrm{m}$ long and $7-13 \mu \mathrm{m}$ diam. in the base, with thickened brown walls, up to $2 \mu \mathrm{m}$ wide, with acute apex and broadened base, coinciding with the description of Pegler (1983). Unfortunately, mature basidia and basidiospores were not observed.

Marasmius neotrichotus has many similarities with other tropical and subtropical South American species: M. spiculosus, M. echinatulus Singer and $M$. araucariae Singer. Marasmius spiculosus (R. Singer B1206 - LIL!). differs in its subcrowded lamellae, gloeocystidioid pleurocystidia and also by the Siccus-type broom cells on the stipe surface (Singer, 1976; Pegler, 1983). Marasmius echinatulus, known from Brazil, Colombia and Argentina, differs in having shorter basidiospores $(6.5-9.7 \times 2.3-4.5 \mu \mathrm{m})$ and metuloid cheilocystidia (more numerous in mature individuals) intermixed with the Siccus-type broom cells (Singer, 1976). Marasmius araucariae is a species described from a adjacent region where these two new species were found. However M. araucariae differs in the thin-walled caulocystidia, 


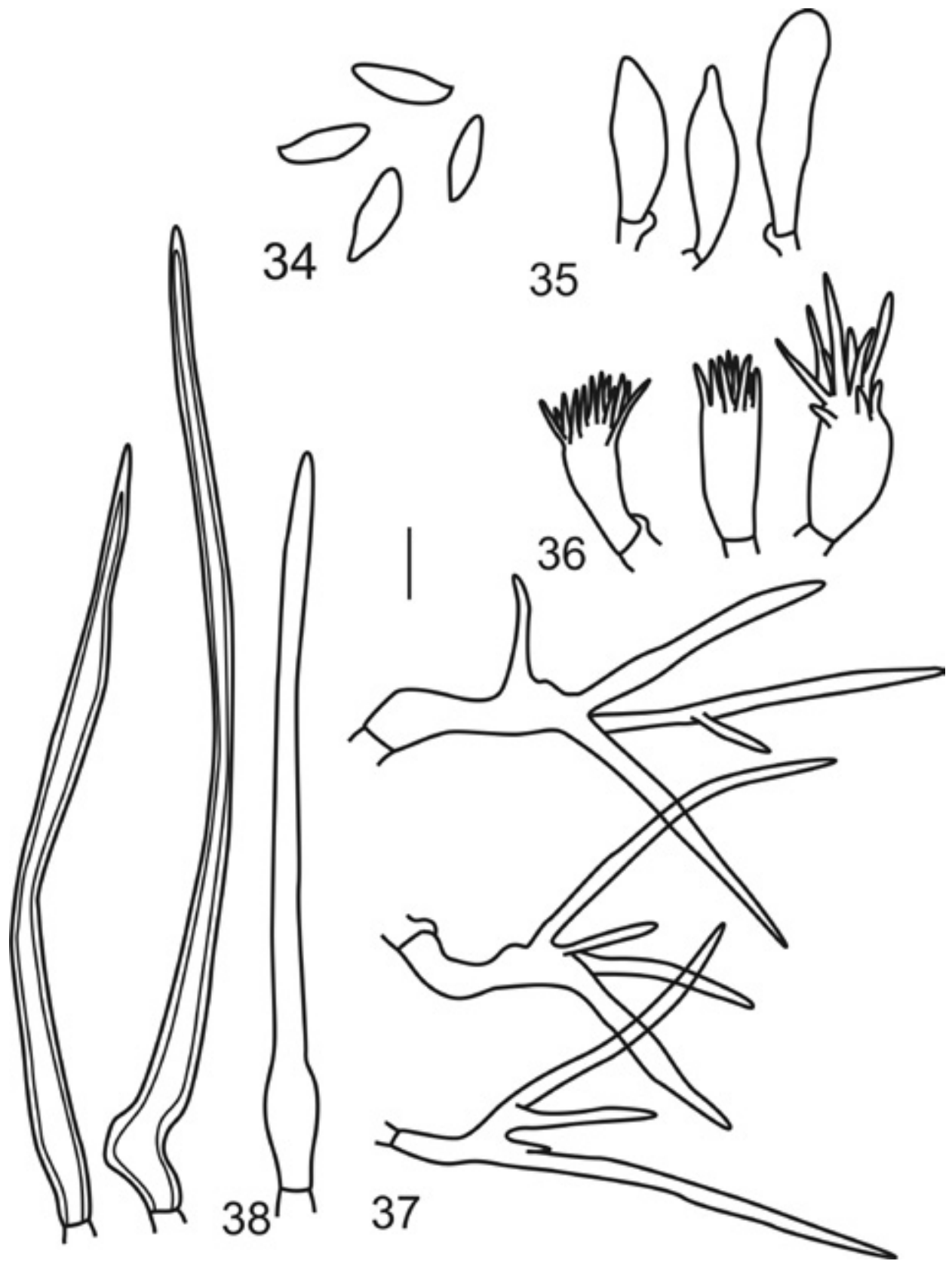

Figs 34-38. M. trichotus microscopic characters. 34. Basidiospores. 35. Basidioles. 36. Cheilocystidia. 37. Pileosetae. 38. Caulosetae. Scale bar $=10 \mu \mathrm{m}$. 
with a rounded apex and shorter than those observed in $M$. neotrichotus (e.g. $50 \times$ $5.5 \mu \mathrm{m}$ ), which leads to be included to stirp Cladophyllus, together with $M$. cladophyllus Berk., as an intermediate species between series Leonini Singer and Actinopodes by Singer (1976).

Marasmius nummularius and Marasmius coklatus Desjardin, Retn. \& E. Horak are other two species of sect. Spinulosi from southern Asia similar to $M$. neotrichotus. However, both have a different stipitipellis, consisting of the Siccustype cells intermixed with setiform caulocystidia, not exceeding $110 \mu \mathrm{m}$ long (Wannathes et al., 2009a); Shay et al. (2017) described only shorter setiform caulocystidia $(28-109 \times 7.2-36 \mu \mathrm{m})$ in the material from Madagascar. In addition, $M$. coklatus has a larger pileus (up to $60 \mathrm{~mm}$ diam.) and well-developed hymenial setae (Desjardin et al., 2000). Marasmius jalapensis Murrill, described from Mexico, differs in having a paler, cream to pale cinnamon brown pileus, crowded lamellae, smaller basidiospores $[(6.9-) 7.7-10(-10.5) \times(3.0-) 3.5-4.7(-5.2) \quad \mu \mathrm{m}]$, welldeveloped hymenial seate, shorter pileosetae $(35-112 \times 9.2-15 \mu \mathrm{m})$ and caulosetae (20-110 × (5.0-)11-13 $\mu \mathrm{m}$; Antonín, 2007).

Marasmius cohaerens (Pers.) Cooke \& Quél. distributed in northern hemisphere, macroscopically resembles $M$. neotrichotus, however, it clearly differs by its yellowish lamellae, glabrous stipe, and smaller basidiospores (Noordeloos, 1995).

\section{DISCUSSION}

The phylogenetic analyses based on molecular data from ITS sequences from the holotype of the two new species here proposed, $M$. chrysoblepharioides and $M$. neotrichotus, confirmed that they are clearly different from other Marasmius species for which ITS data are available. Unfortunately, there are no available sequences for $M$. chrysoblepharis and $M$. nummularioides, the most phenotypically similar species to $M$. chrysoblepharioides, nor for $M$. ciliatus, the other similar species that together with $M$. trichotus and $M$. neotrichotus would constitute a species complex. However, for these species morphological data allowed to establish that they are different taxa. Both new species belong to the traditional sect. Sicci of Singer (1976), or the current concept of the sect. Globulares (Antonín \& Noordeloos, 2010), which include the artificial traditional sect. Sicci and Globulares sensu Singer. Shay et al. (2017) noted already that small groups of species within each infrageneric group of the sect. Sicci (Haematocephali, Leonini, Spinulosi and Atrorubentes) form clades but with limited support. We observed this in our analyses, especially in the ser. Spinulosi and Atrorubentes, which are the best represented series in this study (Fig 1). The two new species are related to other species of the ser. Spinulosi forming a monophyletic group with low support, in which two species of the ser. Atrorubentes (M. xestocephalus and M. iras) are included. Marasmius chrysoblepharioides is phylogenetically related to the remaining species into clade Spinulosi + Atrorubentes p.p. (Fig 1).

Our phylogenetic analyses detected a genetic distance between the sequences of the holotype and paratype of $M$. chrysoblepharioides. As both sequences are almost identical, this distance could probably be a result of the non-optimal quality of the sequence MF683957. In addition, both specimens are morphologically identical, clearly belonging to the same species. 
Marasmius neotrichotus is phylogenetically closely related to M. trichotus, the most phenotypically similar species (Fig 1).

Acknowledgments. This research was possible by the support of Reserva de Biosfera Yaboty, MERNRyT-Proyecto Regional Araucaria XXI, Bosque Atlántico-AECID; Myndel Botanical Foundation; Secretaría General de Ciencia y Técnica, Universidad Nacional del Nordeste (SGCyT-UNNE) and the Consejo Nacional de Investigaciones Científicas y Técnicas (CONICET) from Argentina (PIP 2014-0714). Authors wish to thank the Ministerio de Recursos Renovables y Turismo of the Misiones province (MERNRyT) and to the Administración de Parques Nacionales (APN) by the collection permits provided. The studies of the seventh author (V.A.) were enabled by the support provided to the Moravian Museum by the Ministry of Culture of the Czech Republic as part of its long-term conceptual development programme for research institutions (DKRVO, ref. MK000094862).

\section{LITERATURE CITED}

ANTONÍN V., 2007 - Monograph of Marasmius, Gloiocephala, Palaeocephala and Setulipes in tropical Africa. Fungus Flora of Tropical Africa 1: 1-177.

ANTONÍN V. \& NOORDELOS M.E., 2010 - A monograph of marasmioid and collybioid fungi in Europe. Eching, IHW-Verlag, $480 \mathrm{p}$.

ANTONÍN V., RYOO R. \& SHIN H.D., 2010 - Marasmioid and gymnopoid fungi of the Republic of Korea. 3. Two new taxa of Marasmius sect. Sicci with caulocystidia and/or setae. Mycotaxon 111: $369-377$.

ANTONÍN V., RYOO R. \& SHIN H.D., 2012 - Marasmioid and gymnopoid fungi of the Republic of Korea. 4. Marasmius sect. Sicci. Mycological Progress 11: 615-638.

BRAGA-NETO R., COSTA LUIZÃO R.C., MAGNUSSON W.E., ZUQUIM G. \& VOLKMER DE CASTILHO C., 2008 - Leaf litter fungi in a Central Amazonian forest: the influence of rainfall, soil and topography on the distribution of fruiting bodies. Biodiversity and Conservation 17: 2701-2712.

CORNER E.J.H., 1996 - The agaric genera Marasmius, Chaetocalathus, Crinipellis, Heimiomyces, Resupinatus, Xerula, and Xerulina in Malesia. Beiheft Nova Hedwigia 111: 1-175.

DARRIBA D., TABOADA G.L., DOALLO R. \& POSADA D., 2012 - jModelTest 2: more models, new heuristics and parallel computing. Nature Methods 9: 772.

DENG C.Y. \& LI T.H., 2011 - Marasmius galbinus, a new species from China. Mycotaxon 115: 495-500.

DENNIS R.W.G., 1951 - Species of Marasmius described by Berkeley from tropical America. Kew Bulletin 6: 153-163.

DESJARDIN D.E., 1989 - The genus Marasmius from the Southern Appalachian Mountains. PhD thesis, University of Tennessee, USA.

DESJARDIN D.E. \& HORAK E., 1997 - Marasmius and Gloiocephala in the South Pacific Region: Papua New Guinea, New Caledonia, and New Zealand taxa. Bibliotheca Mycologica 168: $1-152$.

DESJARDIN D. \& OVREBO C.L., 2006 - New species and new records of Marasmius from Panamá. Fungal Diversity 21: 19-39.

DESJARDIN D.E., RETNOWATI A. \& HORAK E., 2000 - Agaricales of Indonesia. 2. A preliminary monograph of Marasmius from Java and Bali. Sydowia 52: 92-193.

FAZEKAS A.J., KUZMINA M.L., NEWMASTER S.G. \& HOLLINGSWORTH P.M., 2012 - DNA barcoding methods for land plants. Methods in Molecular Biology 858: 223-275.

GARDES M. \& BRUNS T.D., 1993 - ITS primers with enhanced specificity of basidiomycetes: Application to the identification of mycorrhizae and rusts. Molecular Ecology 2: 113-118.

GUINDON S. \& GASCUEL O., 2003 - A simple, fast and accurate algorithm to estimate large phylogenies by maximum likelihood. Systematic Biology 52: 696-704.

IVANOVA N.V., DEWAARD J. \& HEBERT P.D.N., 2006 - An inexpensive, automation-friendly protocol for recovering high-quality DNA. Molecular Ecology Notes 6: 998-1002.

IVANOVA N.V., FAZEKAS A.J. \& HEBERT P.D.N., 2008 - Semi-automated, membrane-based protocol for DNA isolation from plants. Plant Molecular Biology Reporter 26: 186-198. 
IVANOVA N.V., KUZMINA M. \& FAZEKAS A., 2016 - CCDB Protocols. Glass fiber plate DNA extraction protocol for plants, fungi, echinoderms and mollusks, Manual protocol employing centrifugation. Available online at http://ccdb.ca/site/wp-ontent/uploads/2016/09/CCDB_ DNA_Extraction-Plants.pdf.

JEEWON R. \& HYDE K.D., 2016 - Establishing species boundaries and new taxa among fungi: recommendations to resolve taxonomic ambiguities. Mycosphere 7: 1669-1677.

KATOH K. \& STANDLEY D.M., 2013 - MAFFT multiple sequence alignment software version 7: improvements in performance and usability. Molecular Biology and Evolution 30: 772-780.

KEARSE M., MOIR R., WILSON A., STONES-HAVAS S., CHEUNG M., STURROCK S., BUXTON S., COOPER A., MARKOWITZ S., DURAN C., THIERER T., ASHTON B., MENTJIES P. \& DRUMMOND A., 2012 - Geneious Basic: an integrated and extendable desktop software platform for the organization and analysis of sequence data. Bioinformatics 28: 1647-1649.

KEREKES J.F. \& DESJARDIN D.E., 2009 - A monograph of the genera Crinipellis and Moniliophthora from Southeast Asia including a molecular phylogeny of the nrITS region. Fungal Diversity 37: 101-152.

KIRK P.M. \& ANSELL A.E., 1992 - Authors of fungal names. Index of Fungi supplement. Available online at http://www.indexfungorum.org/AuthorsOfFungalNames.htm

KIRK P.M., CANNON P.F., MINTER D.W. \& STALPERS J.A., 2008 - Dictionary of the fungi. 10th edn. Wallingford, CABI Europe, $771 \mathrm{p}$.

KIYASHKO A.A., MALYSHEVA E.F., ANTONIN V., SVETASHEVA T.Y.U. \& BULAKH E.M., 2014 - Fungi of the Russian Far East 2. New species and new records of Marasmius and Cryptomarasmius (Basidiomycota). Phytotaxa 186: 1-28.

KORNERUP A. \& WANSCHER J.H., 1978 - Methuen handbook of colour. 3rd edn. London, UK: Eyre Methuen. $252 \mathrm{p}$.

LARGENT D.L., 1986 - How to identify mushrooms to genus I: macroscopic features. 3rd edn. Eureka, California: Mad River Press. 165 p.

LECHNER B.E. \& PAPINUTTI L., 2011 - A new species of Marasmius from northern Argentina. Mycotaxon 118: 251-256.

LÓPEZ-QUINTERO C.A., STRAATSMA G., FRANCO-MOLANO A.E. \& BOEKHOUT T., 2012 Macrofungal diversity in Colombian Amazon forest varies with regions and regimes of disturbance. Biodiversity and Conservation 21: 2221-2243.

MILLER M.A., PFEIFFER W. \& SCHWARTZ T., 2010 - Creating the CIPRES Science Gateway for Inference of Large Phylogenetic Trees. In: SC10 Workshop on Gateway Computing Environments (GCE10). New Orleans, USA, pp. 88.

MOSER M., 1983 - Keys to Agarics and Boleti (Polyporales, Boletales, Agaricales, Russulales). London, Roger Phillips, $535 \mathrm{p}$.

NIVEIRO N. \& ALBERTÓ E.O., 2013 - Checklist of the Argentine Agaricales 4. Tricholomataceae and Polyporaceae. Mycotaxon 121: 499.

NIVEIRO N., ZULIANI P., RAMIREZ N.A., POPOFF O.F. \& ALBERTÓ E.O., 2014 — Clave de identificación de los Agaricales de las Yungas argentinas. Lilloa 51: 74-86.

NOORDELOOS M., 1995 - Tribus Marasmiae Fay. In: Bas C, Kuyper TW, Noordeloos ME \& Vellinga EC (eds.), Flora Agaricina Neerlandica. Rotterdam, A.A. Balkema Publisher, pp. 135-153.

OLIVEIRA J.J.S., SANCHEZ-RAMIREZ S. \& CAPELARI M., 2014 - Some new species and new varieties of Marasmius (Marasmiaceae, Basidiomycota) from Atlantic rainforest areas of São Paulo State, Brazil. Mycological Progress 13: 923-949.

PAPINUTTI L. \& LECHNER B.E., 2011 - Two new species of Marasmius (Basidiomycetes, Marasmiaceae) from a xeric zone of Argentina. Cryptogamie Mycologie 32: 219-225.

PEGLER D.N., 1983 - Agaric flora of Lesser Antilles. Kew Bulletin Additional Series 9: 1-668.

PEGLER D.N., 1986 - Agaric flora of Sri Lanka. Kew Bulletin Additional Series 12: 1-518.

RAITHELHUBER J., 2004 - Nueva flora micológica Argentina. Stuttgart, Germany: Mycosur. 576 p.

RAMBAUT A., SUCHARD M.A., XIE D. \& DRUMMOND A.J., 2014 - Tracer, Version 1.6. Available at: http://tree.bio.ed.ac.uk/software/tracer/.

RONQUIST F. \& HUELSENBECK J.P., 2003 - MrBayes version 3.0: Bayesian phylogenetic inference under mixed models. Bioinformatics 19: 1572-1574.

RYOO R., ANTONÍN V., KA K.H. \& SHIN H.D., 2013 — Note on the new Korean common names of marasmioid fungi. 1. The genus Marasmius. The Korean Journal of Mycology 41: 280286.

SCHNEIDER C.A., RASBAND W.S. \& ELICEIRI K.W., 2012 - NIH Image to ImageJ: 25 years of image analysis. Nature Methods 9: 671-675. 
SCHOCH C.L., SEIFERT K.A., HUHNDORF S., ROBERT V., SPOUGE J.L., LEVESQUE C.A. \& CHEN W., Fungal Barcoding Consortium, 2012 - Nuclear ribosomal internal transcribed spacer (ITS) region as a universal DNA barcode marker for Fungi. Proceedings of the National Academy of Sciences of the United States of America 109: 6241-6246.

SHAY J.E., DESJARDIN D.E., PERRY B.A., GRACE C.L. \& NEWMAN D.S., 2017 - Biodiversity and phylogeny of Marasmius (Agaricales, Basidiomycota) from Madagascar. Phytotaxa 292: 101-149.

SINGER R., 1958 - Studies toward a monograph of the South American species of Marasmius. Sydowia 12: 54-145.

SINGER R., 1965 - Monographic studies of South American Basidiomycetes, especially those of the east slope of the Andes and Brazil. 2. The genus Marasmius in South America. Sydowia 18: $106-358$.

SINGER R., 1976 - Marasmieae (Basidiomycetes, Tricholomataceae). Flora Neotropica Monographs 17: $1-347$.

SINGER R., 1986 - The Agaricales in modern taxonomy. 4th edn. Koenigstein, Koeltz Scientific Books, $981 \mathrm{p}$.

SINGER R., 1989 - New taxa and new combinations of Agaricales (Diagnoses fungorum novorum Agaricalium IV). Fieldiana Botany 21: 1-133.

STAMATAKIS A., 2014 - RaxML Version 8: A tool phylogenetic analysis and post-analysis of large phylogenies. Bioinformatics 30: 1312-1313.

TAKAHASHI H., 2000 - Three new species of Marasmius section Sicci from eastern Honshu, Japan. Mycoscience 41: 313-321.

TAMURA K., PETERSON D., PETERSON N., STECHER G., NEI M. \& KUMAR S., 2011 MEGA5: molecular evolutionary genetics analysis using maximum likelihood, evolutionary distance, and maximum parsimony methods. Molecular Biology and Evolution 28: 27312739.

TAN Y.S., DESJARDIN D.E., VIKINESWARY S. \& ABDULLAH N., 2007 - New species and mating studies of Marasmius from Malaysia. Fungal Diversity 25: 187-217.

TAN Y.S., DESJARDIN D.E., PERRY B.A., VIKINESWARY S., NOORLIDAH A., 2009 — Marasmius sensu stricto in Peninsular Malaysia. Fungal Diversity 37: 9-100.

THIERS B., 2017 (continuously updated) - Index Herbariorum: A global directory of public herbaria and associated staff. New York Botanical Garden's Virtual Herbarium. http://sweetgum.nybg. org/ih/.

WANNATHES N., DESJARDIN D.E., HYDE K.D., PERRY B.A. \& LUMYONG S., 2009a - A monograph of Marasmius (Basidiomycota) from Northern Thailand based on morphological and molecular (ITS sequences) data. Fungal Diversity 37: 209-306.

WANNATHES N., DESJARDIN D.E. \& LUMYONG S., 2009b - Four new species of Marasmius section Globulares from Northern Thailand. Fungal Diversity 36: 155-163. 